\title{
Apple varieties of selection of "All-Russian Research Institute of Fruit Crops Breeding", as a starting material for breeding for a high content of phenolic compounds in fruits
}

\author{
Margarita Makarkina*, and Evgeny Sedov
}

Federal State Budgetary Scientific Institution "All-Russian Scientific Research Institute for Breeding Fruit Crops", 302530, Oryol Region, Oryol District, village Zhilina

\begin{abstract}
The All-Russian Scientific Research Institute for Breeding Fruit Crops is the oldest pomological institution. The scientific direction of the institute is to obtain genotypes of fruit crops that exceed the standard ones in terms of basic economic indicators, including those with an improved chemical composition of fruits. The leading culture is the apple tree. One of the indicators of the chemical composition of apples is the presence of phenolic compounds, the most important natural antioxidants: catechins and polyphenols. Genotypes of different maturation periods, immune (Rvi6) and resistant (Rvi5) to scab, diploids (2x) and triploids (3x), vigorous and intensive type (Co gene), were identified as sources of the studied traits. The best in terms of the accumulation of catechins were the varieties of the autumn ripening period: Sokovinka, Slavyanin, Pamyat Isaeva, Zaryanka, Orlovsky pioneer, origin - Antonovka red barrel $\times$ SR0523 (159.0-288.0 mg / $100 \mathrm{~g}$ ); the summer varieties - Zhelnoe, Orlovim, Early aloe, Anniversary (152.0-170.0 mg / $100 \mathrm{~g})$, the winter varieties - Kurnakovskoe, Olympic, Poetry, Freshness, Bezhin meadow, Kulikovskoe, Start, Health, Academician Savelyev, Festive, Orlovskaya Zarya, Pamyati Blynsky, Vita, Mars, Imrus, Pamyati Semakina, Celandine, Kandil Orlovsky, Morning Star, $(161.2-353.5 \mathrm{mg} / 100 \mathrm{~g})$. The sources of the total amount of polyphenols (more than $400.0 \mathrm{mg} / 100 \mathrm{~g}$ ) were selected: with the Rvi6 gene - Start, Zaryanka, Ivanovskoe, Imrus, Oryol woodland, Zdorov'e, Bolotovskoe, Pamyati Khitrovo, Kandil Orlovsky; with the Rvi5 gene - Orlovsky pioneer and Celandine; triploids - Memory Semakin, Bezhin lug, Turgenevskoe, Mars, Orlovsky partisan, Trainer Petrov, Patriot, Augusta (404.0-623.9 mg / 100 g), of which the varieties Mars and Trainer Petrov have the Rvi6 gene.
\end{abstract}

\section{Introduction}

To maintain a healthy lifestyle, the human body needs a varied diet with a predominance of fruits and vegetables. The main substances that have a positive effect on metabolism, redox reactions occurring in it are antioxidants, in particular vitamins. Phenolic compounds (vitamin P), mostly flavonoids, have an irreplaceable function among them $[1,2,3,4]$.

\footnotetext{
* Corresponding author: makarkina.m@mail.ru
} 
Phenolic compounds have a beneficial effect on the hematopoietic system of the body, together with other antioxidants; they reduce the risk of asthma, diabetes, cancer, obesity, and cardiovascular diseases. They are actively involved in the treatment of gastrointestinal ulcers $[5,6,7,8]$. It is phenolic compounds that have the greatest antioxidant activity; they are able to absorb reactive oxygen and nitrogen species, which are directly involved in the occurrence of a number of inflammatory and other diseases [8].

The apple fruits are not an exception, they are rich in sufficient quantities of polyphenols: flavonoids (flavonols, catechins, leukoanthocyanins), hydroxycinnamic acids, procyanidins, chlorogenic acid, etc. $[9,10,11]$. According to many researchers, apples are fruits with the highest content of phenolic compounds $[1,5]$.

It is noted that there is a strong correlation between the content of phenolic compounds in apples and their antioxidant activity. According to J. Boyer, R.H. Liu (2004) the apple fruits have the second (after cranberry) highest level of antioxidants compared to other commonly consumed fruits such as lemon, strawberry, peach, red grapes, etc. [1]. It is the chlorogenic acid and catechins present in apples that "cleanse" the body of free radicals and take part in enzymatic metabolism $[5,6,10,11]$. The amount of polyphenols in apple fruits is influenced by the varietal affiliation caused by significant genetic variability of polyphenolic traits $[12,13]$. In the apples, phenolic compounds are not evenly distributed; the largest amount (per unit weight) is in the skin, less in the pulp and seeds [13, 14].

The apple tree occupies one of the leading places among the cultivated fruit crops in the world, behind bananas and citrus fruits. Apples are currently produced in 51 countries. Despite the large number of fruits produced in the world, the world's population prefers apples to many others $[15,16]$. This is due to its adaptability to various soil and climatic conditions, a wide range of varieties and species. In Russian Federation, apple one of the favorite crops of the population, producing fruit products, $51 \%$ of the residents of Russian cities prefer apples from the offered assortment of fruits. It should be noted that until 1990 the production of apples in the USSR increased to $24-26$ million tons and reached $66-70 \mathrm{~kg}$ per capita against $38 \mathrm{~kg}$ in 1980, by 2009 it dropped to $25-30 \mathrm{~kg}$. At present time, Russian gardening is undergoing a recovery stage: the young orchards are been planted, including apple orchards [17]. At the same time, the issue of creating varieties of a new generation remains important. A special direction in the breeding program of berry and fruit crops, including apple trees, is to obtain new varieties with fruit quality indicators, including biochemical ones, exceeding standard ones. Hence, the task arises - to study the existing gene pool with the subsequent selection of the best varieties (donors and sources) according to the traits under study. The All-Russian Research Institute for Breeding Fruit Crops (VNIISPK) is the oldest pomological institution, which has created a large number of varieties of fruit and berry crops, including more than 80 varieties of apple trees.

The purpose of these studies is to conduct a comparative assessment of apple varieties of VNIISPK selection by the amount of phenolic substances accumulated in fruits with further isolation and recommendation of the best genotypes for a comprehensive breeding program.

\section{Objects and methods of research}

The objects of the research were 75 varieties of apple fruits, created in the institute presented in this article, grown in the plots of variety study, different in terms of ripening. Average annual data for 2000-2019 are presented, the study of one variety was carried out for 3-5 years. P-active catechins and the amount of polyphenolic compounds were studied in apple fruits. Biochemical studies were carried out in the laboratory for biochemical and technological assessment of varieties and storage of the Institute, using the generally accepted methods: "Program and methodology for the study of varieties of fruit, berry and nut crops" (Orel: VNIISPK, 1999). Phenolic compounds were determined by a photometric method 
modified by L. I. Vigorov (Vigorov, 1968) using a FEK KFK-3-01 "ZOMS" photocolorimeter: P-active catechins were determined on the optical density scale in an alcoholic extract using a vanillin reagent. In the mathematical processing of the data, the analysis package of the Microsoft Excel program was used.

\section{Results and discussion}

The studied varieties were grouped according to the ripening periods: summer - 15 varieties, autumn - 8, winter - 52 varieties. The studied varieties have different origins: different ploidy (2x and 3x), resistance or immunity (Rvi5, Rvi6) to scab, different strength of tree growth. At present, much attention is paid to the creation of varieties immune to scab, triploid ( $3 x)$, with restrained growth (columnar - Co), as well as containing the listed genes in their genotype at the same time, that is, three in one. Along with this, when obtaining new genotypes, a special place is occupied by the direction - the creation of varieties with improved biochemical indicators of the quality of fruits, including biologically active ones, which determine the antioxidant activity of the product being created.

For the studied three groups of apple varieties, the largest amount of catechins (average value) in fruits was obtained in autumn varieties $185.9 \pm 18.8 \mathrm{mg} / 100 \mathrm{~g}$, slightly less - in winter varieties $-153.8 \pm 6.3 \mathrm{mg} / 100 \mathrm{~g}$, and more less - in summer patients $142.3 \pm 4.6 \mathrm{mg}$ / $100 \mathrm{~g}$ (Tables 1, 2,3). In each group, it is necessary to distinguish varieties, in the fruits of which a greater amount of catechins accumulated in comparison with the average value and the indicator in the control varieties.

Table 1. Content of vitamin $P$ in apples of summer ripening.

\begin{tabular}{|l|c|c|c|}
\hline \multirow{2}{*}{ Variety } & \multicolumn{3}{|c|}{ Content } \\
\cline { 2 - 4 } & $\begin{array}{c}\text { P-active } \\
\text { catechins, mg / } \\
100 \mathrm{~g}\end{array}$ & $\begin{array}{c}\text { the amount of } \\
\text { polyphenols, mg } \\
/ 100 \mathrm{~g}\end{array}$ & soluble solids, \% \\
\hline Radost' Nadezhdy & 135,7 & 473,8 & 12,75 \\
\hline Avgusta (3kh)* & 148,5 & 409,1 & 12,81 \\
\hline Zhelannoye & 163,8 & 382,0 & 12,34 \\
\hline Yablochnyy Spas (3kh, Rvi6)* & 128,4 & 369,3 & 12,39 \\
\hline Tikhiy Don (3kh, Rvi6)* & 166,0 & 364,9 & 12,43 \\
\hline Yubilyar (3kh, Rvi6)* & 157,6 & 363,0 & 11,12 \\
\hline Darona (3kh)* & 139,1 & 336,9 & 13,53 \\
\hline Spasskoye (3kh, Rvi6)* & 134,4 & 333,7 & 12,91 \\
\hline Zhilinskoye (3kh, Rvi6)* & 128,2 & 329,7 & 12,22 \\
\hline Orlinka & 145,2 & 314,4 & 11,29 \\
\hline Podarok uchitelyu & 138,5 & 308,6 & 12,44 \\
\hline Orlovim (Rvi5)* & 151,9 & 298,7 & 11,88 \\
\hline Ranneye aloye & 170,0 & 298,0 & 11,68 \\
\hline Maslovskoye (3kh, Rvi6)* & 105,0 & 288,0 & 12,24 \\
\hline Osipovskoye (3kh)* & 122,7 & 265,7 & 13,21 \\
\hline Average, $\overline{\mathbf{x}} \pm \mathbf{m}$ & $\mathbf{1 4 2 , 3 \pm 4 , 6}$ & $\mathbf{3 4 2 , 4 \pm 1 3 , 8}$ & $\mathbf{1 2 , 3 5 \pm 0 , 1 7}$ \\
\hline Min & $\mathbf{1 0 5 , 0}$ & $\mathbf{2 6 5 , 7}$ & $\mathbf{1 1 , 1 2}$ \\
\hline Max & $\mathbf{1 7 0 , 0}$ & $\mathbf{4 7 3 , 8}$ & $\mathbf{1 3 , 5 3}$ \\
\hline Variation coefficient, V\% & $\mathbf{1 2 , 5}$ & $\mathbf{1 5 , 4}$ & $\mathbf{5 , 4}$ \\
\hline Papirovka - control & 141,1 & 258,6 & 11,22 \\
\hline
\end{tabular}

* - 3x - triploid varieties; Rvi5, Rvi6 - genes for scab immunity. 
Among the varieties of summer ripening (Table 1), the following varieties stand out: Zhelannoye, Orlovim, Early aloe, Yubilyar (151.9-170.0 mg / 100 g). All these varieties are of different origins. But in the varieties obtained from the Papirovka tetraploid variety: Maslovskoe, Osipovskoe, Zhilinskoe, Spasskoe, Daryona, August, the content of catechins is low (105.0-148.5 mg / $100 \mathrm{~g})$.

In the control variety Papirovka, P-active catechins in fruits accumulated at the level of an average value of $141.1 \mathrm{mg} / 100 \mathrm{~g}$.

Among the eight autumn varieties (Table 2), cultivars were distinguished (in ascending order of the indicator), originating from the Antonovka krasnobochka variety and the SR0523 form: Sokovinka, Slavyanin, Pamyat Isaeva, Zaryanka, Orlovsky pioneer, (158.9-287.9 mg / $100 \mathrm{~d}$ ), excluding variety Pervinka - $123.9 \mathrm{mg} / 100 \mathrm{~g}$. In the control variety Osenneye polosatoye, the content of catechins in fruits was the lowest in the studied group - $96.9 \mathrm{mg}$ / $100 \mathrm{~g}$.

Table 2. The content of vitamin $P$ in apples of autumn ripening.

\begin{tabular}{|l|c|c|c|}
\hline \multirow{2}{*}{ Variety } & \multicolumn{3}{|c|}{ Content } \\
\cline { 2 - 4 } & $\begin{array}{c}\text { P-active } \\
\text { catechins, } \\
\mathrm{mg} / 100 \mathrm{~g}\end{array}$ & $\begin{array}{c}\text { the amount of } \\
\text { polyphenols, } \\
\mathrm{mg} / 100 \mathrm{~g}\end{array}$ & soluble solids, \% \\
\hline Orlovskiy pioner (Rvi5)* & 287,9 & 514,1 & 12,79 \\
\hline Zaryanka (Rvi5)* & 224,4 & 418,9 & 12,42 \\
\hline Sokovinka & 158,9 & 364,2 & 10,16 \\
\hline Slavyanin & 197,8 & 361,1 & 12,76 \\
\hline Solnyshko (Rvi6)* & 148,7 & 349,5 & 12,58 \\
\hline Orlovskoye polosatoye & 145,8 & 261,3 & 12,87 \\
\hline Pamyat' Isayeva & 200,0 & 325,2 & 12,02 \\
\hline Pervinka & 123,9 & 282,9 & 12,13 \\
\hline Average, $\overline{\mathbf{x}} \pm \mathbf{m}$ & $\mathbf{1 8 5 , 9 \pm 1 8 , \boldsymbol { 8 }}$ & $\mathbf{3 5 9 , 7 \pm 2 8 , 1}$ & $\mathbf{1 2 , 2 2 \pm 0 , 3 1}$ \\
\hline Min & $\mathbf{1 2 3 , 9}$ & $\mathbf{2 6 1 , 3}$ & $\mathbf{1 0 , 1 6}$ \\
\hline Max & $\mathbf{2 8 7 , 9}$ & $\mathbf{5 1 4 , 1}$ & $\mathbf{1 2 , 8 7}$ \\
\hline Variation coefficient, V\% & $\mathbf{2 8 , 6}$ & $\mathbf{2 2 , 1}$ & $\mathbf{7 , 3}$ \\
\hline Osenneye polosatoye - control & $\mathbf{9 6 , 9}$ & 247,9 & 12,02 \\
\hline
\end{tabular}

*-Rvi5, Rvi6-genes for scab immunity.

The most numerous is the group of varieties of winter origin (Table 3). Above the average value for this group of varieties $(160.0 \mathrm{mg} / 100 \mathrm{~g}$ and more), the content of catechins in fruits was (in ascending order of the indicator): Kurnakovskoe, Olympic, Poetziya, Freshness, Bezhin lug, Kulikovskoe, Start, Health, Academician Savelyev, Festive, Orlovskaya dawn, In memory of Blynsky, Vita, Mars, Imrus, Memory for Semakin, Celandine, Kandil Orlovsky, Morning star, (161.2-353.5 mg / $100 \mathrm{~g})$. In the control cultivars Antonovka ordinary and Severny Sinap, this indicator was significantly lower than the average value for the group - 108.8 and $79.2 \mathrm{mg} / 100 \mathrm{~g}$, respectively.

Table 3. The content of vitamin $P$ in apples of winter ripening.

\begin{tabular}{|l|c|c|c|}
\hline \multirow{2}{*}{ Variety } & \multicolumn{3}{|c|}{ Content } \\
\cline { 2 - 4 } & $\begin{array}{c}\text { P-active } \\
\text { catechins, } \\
\mathrm{mg} / 100 \mathrm{~g}\end{array}$ & $\begin{array}{c}\text { the amount of } \\
\text { polyphenols, } \\
\mathrm{mg} / 100 \mathrm{~g}\end{array}$ & soluble solids, $\%$ \\
\hline Morning star & 353,5 & 623,9 & 13,99 \\
\hline Kandil' orlovskiy (Rvi6)* & 242,4 & 557,9 & 12,21 \\
\hline
\end{tabular}




\begin{tabular}{|c|c|c|c|}
\hline Vita & 185,3 & 485,8 & 13,29 \\
\hline Pamyati Khitrovo (Rvi6)* & 141,8 & 480,2 & 12,14 \\
\hline Bolotovskoye (Rvi6)* & 193,9 & 477,2 & 12,62 \\
\hline Pamyat' Semakinu (3kh)* & 221,4 & 473,6 & 11,78 \\
\hline Chistotel (Rvi5)* & 236,9 & 458,8 & 11,89 \\
\hline Zdorov'ye (Rvi6)* & 167,2 & 450,0 & 12,61 \\
\hline Bezhin lug (3kh)* & 161,6 & 448,9 & 12,09 \\
\hline Turgenevskoye (3kh)* & 131,4 & 444,1 & 14,18 \\
\hline Mars( 3kh, Rvi6)* & 215,1 & 439,2 & 12,30 \\
\hline Orlovskoye poles'ye (Rvi6)* & 154,9 & 438,2 & 12,81 \\
\hline Imrus (Rvi6)* & 215,3 & 432,9 & 12,59 \\
\hline Ivanovskoye (Rvi6)* & 110,0 & 432,4 & 13,82 \\
\hline Orlovskiy partizan $(3 \mathrm{kh})^{*}$ & 144,3 & 425,9 & 13,54 \\
\hline Trener Petrov (3kh, Rvi6)* & 142,3 & 417,8 & 13,79 \\
\hline Patriot $(3 \mathrm{kh}) *$ & 134,0 & 410,1 & 12,89 \\
\hline Start (Rvi6)* & 163,8 & 404,2 & 14,14 \\
\hline Stroyevskoye (Rvi6)* & 158,7 & 396,3 & 13,09 \\
\hline Pamyati Blynskogo & 182,0 & 391,1 & 14,33 \\
\hline Kurnakovskoye (Rvi6)* & 161,2 & 382,3 & 13,42 \\
\hline Blagodat' (3kh)* & 131,1 & 378,7 & 13,78 \\
\hline Svezhest' (Rvi6)* & 161,4 & 376,9 & 12,26 \\
\hline Prazdnichnoye (3kh, Rvi6)* & 172,4 & 367,8 & 14,59 \\
\hline Rozhdestvenskoye (3kh, Rvi6)* & 128,5 & 367,8 & 12,12 \\
\hline Ministr Kiselev (3kh)* & 146,0 & 364,9 & 12,57 \\
\hline Zvezda efira & 145,1 & 364,8 & 13,38 \\
\hline Afrodita (Rvi6)* & 128,0 & 361,4 & 13,14 \\
\hline Poeziya $(\mathrm{Co}, \mathrm{Rvi6})^{*}$ & 161,2 & 351,9 & 12,23 \\
\hline Yubiley Moskvy (Rvi6)* & 158,0 & 351,8 & 12,81 \\
\hline Den' Pobedy $(3 \mathrm{kh})^{*}$ & 125,9 & 349,0 & 13,59 \\
\hline Vavilovskoye (3kh, Rvi6)* & 150,0 & 345,0 & 14,63 \\
\hline Priokskoye $(\mathrm{Co}, \mathrm{Rvi6})^{*}$ & 140,8 & 341,2 & 13,72 \\
\hline Orlovskaya zarya & 176,9 & 335,1 & 13,65 \\
\hline Aleksandr Boyko (3kh, Rvi6)* & 102,9 & 330,0 & 12,43 \\
\hline Akademik Savel'yev (3kh)* & 170,1 & 323,0 & 13,12 \\
\hline Kulikovskoye & 166,3 & 317,4 & 12,77 \\
\hline Orlovskaya Yeseniya $(\mathrm{Co})^{*}$ & 120,0 & 312,0 & 14,09 \\
\hline Vostorg (Co, Rvi6)* & 112,3 & 306,0 & 12,77 \\
\hline Nizkorosloye $(3 \mathrm{kh})^{*}$ & 153,4 & 292,9 & 12,42 \\
\hline Olimpiyskoye & 161,2 & 280,1 & 13,83 \\
\hline Sozvezdiye (Co Rvi6)* & 124,0 & 267,9 & 13,25 \\
\hline Buninskoye & 154,8 & 250,4 & 11,91 \\
\hline Morozovskoye & 127,3 & 299,3 & 12,18 \\
\hline Pepin orlovskiy & 146,1 & 241,3 & 12,51 \\
\hline Ven'yaminovskoye (Rvi6)* & 94,8 & 234,9 & 13,08 \\
\hline Girlyanda (Co, Rvi6)* & 92,9 & 231,5 & 12,63 \\
\hline Veteran & 139,6 & 230,2 & 12,72 \\
\hline Orlik & 100,0 & 221,7 & 12,79 \\
\hline Sinap orlovskiy $(3 \mathrm{kh})^{*}$ & 100,9 & 205,1 & 12,33 \\
\hline
\end{tabular}




\begin{tabular}{|l|c|c|c|}
\hline Pamyat' voinu & 99,1 & 182,3 & 13,39 \\
\hline Prishvinskoye & 89,9 & 147,3 & 12,14 \\
\hline Average, $\overline{\mathbf{x}} \pm \mathbf{m}$ & $\mathbf{1 5 3 , 8 \pm 6 , 3}$ & $\mathbf{3 6 1 , 5 \pm 1 3 , 3}$ & $\mathbf{1 3 , 0 0 \pm 0 , 1 1}$ \\
\hline Min & $\mathbf{8 9 , 9}$ & $\mathbf{1 4 7 , 3}$ & $\mathbf{1 1 , 7 8}$ \\
\hline Max & $\mathbf{3 5 3 , 5}$ & $\mathbf{6 2 3 , 9}$ & $\mathbf{1 4 , 6 3}$ \\
\hline Variation coefficient, V\% & $\mathbf{2 9 , 6}$ & $\mathbf{2 6 , 4}$ & $\mathbf{5 , 8}$ \\
\hline Cultural average, $\mathbf{X} \pm \mathbf{m}$ & $\mathbf{1 5 4 , 9 \pm 5 , 0}$ & $\mathbf{3 5 7 , 5 \pm 1 0 , 0}$ & $\mathbf{1 2 , 7 9 \pm 0 , 0 9}$ \\
\hline Min & $\mathbf{8 9 , 9}$ & $\mathbf{1 4 7 , 3}$ & $\mathbf{1 0 , 1 6}$ \\
\hline Max & $\mathbf{3 5 3 , 5}$ & $\mathbf{6 2 3 , 9}$ & $\mathbf{1 4 , 6 3}$ \\
\hline Variation coefficient, V\% & $\mathbf{2 8 , 6}$ & $\mathbf{2 4 , 2}$ & $\mathbf{6 , 3}$ \\
\hline Antonovka ordinary - control & 108,8 & 339,6 & 11,3 \\
\hline North synap - control & 79,2 & 136,8 & 11,2 \\
\hline
\end{tabular}

* - 3x - triploid varieties; Rvi5, Rvi6 - genes for scab immunity; Co - columnar gene.

The accumulation of the total amount of phenolic compounds shows the same tendency: summer genotypes accumulated a smaller amount $-342.4 \pm 13.8 \mathrm{mg} / 100 \mathrm{~g}$, autumn and winter - slightly more $359.7 \pm 28.1$ and $361.5 \pm 13.3 \mathrm{mg} / 100 \mathrm{~g}$, respectively, while the summer varieties showed less varietal variability.

In accordance with the requirements for newly created varieties, indicated in the "Program and methodology for the selection of fruit, berry and nut crops" (Orel, 1995), in apples produced for the Central Black Earth region of Russia, vitamin P must accumulate at least $200.0 \mathrm{mg} / 100 \mathrm{~g}$.

Almost all apple varieties created at our institute meet this requirement, with the exception of two varieties - Pamyat' voinu (182.3 mg / $100 \mathrm{~g})$ and Prishvinskoe (147.3 mg / $100 \mathrm{~g}$ ), while the total amount of polyphenolic substances by for all varieties ranged from 147.3 to $624.0 \mathrm{mg} / 100 \mathrm{~g}$ and averaged $357.5 \pm 10.0 \mathrm{mg} / 100 \mathrm{~g}$, with a variation coefficient of $24.3 \%$ slightly higher than the average value $(\mathrm{V} \%)$. Coefficients of pair correlation $(\mathrm{r})$ were calculated to establish the contingency of features. The content of soluble solids and catechins, soluble solids and the total amount of P-active substances do not depend on $-\mathrm{r}=$ 0.022 and +0.109 , respectively, a relatively high positive relationship was established between the content of catechins and the total amount of phenolic substances $\mathrm{r}=0.70 * * *$.

From the three groups, we have identified varieties with a total content of phenolic compounds of more than $400.0 \mathrm{mg} / 100 \mathrm{~g}$ : Morning Star, Kandil' orlovskiy, Orlovskiy pioner, Vita, Pamyati Khitrovo, Bolotovskoye, Pamyat' Semakinu, Radost' Nadezhdy, Chistotel, Bezhin lug, Zdorov'ye, Turgenevskoye, Mars, Orlovskoye poles'ye, Imrus, Ivanovskoye, Orlovskiy partizan, Zaryanka, Trener Petrov, Patriot, Avgusta, Start.

All these varieties are of interest for further use in breeding programs as donors and sources for the high content of phenolic compounds in apples.

These varieties are valuable not only for this indicator, the varieties Start, Zaryanka, Ivanovskoye, Imrus, Orlovskoye poles'ye, Zdorov'ye, Bolotovskoye, Pamyati Khitrovo, Kandil' orlovskiy have the Rvi6 gene in their genotype; Orlovsky Orlovskiy pioner and Chistotel- Rvi5; varieties Avgusta, Bezhin lug, Mars, Orlovskiy partizan, Pamyat' Semakinu, Patriot, Trener Petrov, Turgenevskoye are triploids (3x), of which the varieties Mars and Trainer Petrov have the Rvi6 gene.

Below is a more complete biochemical characteristic of the varieties isolated by the content of phenolic substances in fruits (Table 4).

In addition to the high content of phenolic substances in the fruits, the varieties such as Morning star, Turgenevskoye, Patriot, Orlovskiy Partizan, Ivanovskoye, showed a high sugar content of more than $11.0 \%$ for the Middle zone of horticulture, while the varieties Vita, Zaryanka, Ivanovskoye, Orlovsky pioneer had more than $14.0 \mathrm{mg} / 100 \mathrm{~g}$. 
Table 4. Characteristics of the biochemical composition of the fruits of apple varieties - sources of phenolic compounds.

\begin{tabular}{|c|c|c|c|c|c|c|}
\hline \multirow[b]{2}{*}{ Variety } & \multicolumn{6}{|c|}{ Content } \\
\hline & $\begin{array}{c}\text { the } \\
\text { amount } \\
\text { of } \\
\text { polyphe } \\
\text { nols, mg } \\
/ 100 \mathrm{~g}\end{array}$ & $\begin{array}{c}\text { P-active } \\
\text { catechin } \\
\mathrm{s}, \mathrm{mg} / \\
100 \mathrm{~g}\end{array}$ & $\begin{array}{c}\text { vitamin } \\
\mathrm{C}, \mathrm{mg} / \\
100 \mathrm{~g}\end{array}$ & $\begin{array}{c}\text { soluble } \\
\text { solids, } \%\end{array}$ & $\begin{array}{c}\text { the total } \\
\text { of } \\
\text { sugars, } \\
\%\end{array}$ & $\begin{array}{l}\text { organic } \\
\text { acids, } \%\end{array}$ \\
\hline Morning star & 623,9 & 353,5 & 10,9 & 13,99 & 12,22 & 0,71 \\
\hline Kandil' orlovskiy & 557,9 & 242,4 & 7,7 & 12,21 & 10,18 & 0,60 \\
\hline Orlovskiy pioner & 514,1 & 287,9 & 15,0 & 12,79 & 10,0 & 0,85 \\
\hline Vita & 485,8 & 185,3 & 24,0 & 13,29 & 10,10 & 0,81 \\
\hline Pamyati Khitrovo & 480,2 & 141,8 & 4,1 & 12,14 & 10,61 & 0,90 \\
\hline Bolotovskoye & 477,2 & 193,9 & 12,0 & 12,62 & 10,54 & 0,39 \\
\hline Radost' Nadezhdy & 473,8 & 135,7 & 5,0 & 12,75 & 10,71 & 0,68 \\
\hline Pamyat' Semakinu & 473,6 & 221,4 & 9,4 & 11,78 & 9,59 & 0,88 \\
\hline Chistotel & 458,8 & 236,9 & 15,0 & 11,89 & 9,71 & 0,83 \\
\hline Zdorov'ye & 450,0 & 167,2 & 8,4 & 12,61 & 9,59 & 0,90 \\
\hline Bezhin lug & 448,9 & 161,6 & 7,4 & 12,09 & 9,61 & 0,58 \\
\hline Turgenevskoye & 444,1 & 131,4 & 5,2 & 14,18 & 11,42 & 0,55 \\
\hline Mars & 439,2 & 215,1 & 11,4 & 12,30 & 10,81 & 0,48 \\
\hline Orlovskoye poles'ye & 438,2 & 154,9 & 7,1 & 12,81 & 9,99 & 0,82 \\
\hline Imrus & 432,9 & 215,3 & 9,8 & 12,59 & 9,71 & 0,69 \\
\hline Ivanovskoye & 432,4 & 110,0 & 20,0 & 13,82 & 11,84 & 0,79 \\
\hline Orlovskiy partizan & 425,9 & 144,3 & 8,7 & 13,54 & 11,78 & 0,45 \\
\hline Zaryanka & 418,9 & 224,4 & 17,8 & 12,42 & 10,13 & 0,75 \\
\hline Trener Petrov & 417,8 & 142,3 & 7,5 & 13,79 & 10,11 & 0,81 \\
\hline Patriot & 410,1 & 134,0 & 7,9 & 12,89 & 11,51 & 0,48 \\
\hline August & 409,1 & 148,5 & 8,8 & 12,81 & 10,90 & 0,75 \\
\hline Start & 404,2 & 163,8 & 11,9 & 14,14 & 10,91 & 0,59 \\
\hline
\end{tabular}

\section{Conclusion}

As a result of long-term studies of 75 varieties of breeding of the All-Russian Scientific Research Institute of Fruit Crops for the content of P-active catechins and the total content of phenolic compounds in fruits, genotypes of different ripening periods, of various origins, immune and scab resistant, having a diploid and triplod set were isolated chromosomes, vigorous and intensive type, as sources of the studied characters.

In the fruits of varieties of the autumn ripening period, the highest average indicator is noted - the content of catechins. The best selected varieties for the accumulation of catechins were the varieties of the autumn ripening period such as Sokovinka, Slavyanin, Pamyat' Isayeva, Zaryanka, Orlovskiy pioner obtained from crossing Antonovka krasnobochka $\times$ SR0523, the varieties of the summer ripening period-Zhelannoye, Orlovim, Ranneye aloye and Yubilyar,, winter ripening period - Kurnakovskoye, Olimpiyskoye, Poeziya, Svezhest', Bezhin lug, Kulikovskoye, Start, Zdorov'ye, Akademik Savel'yev, Prazdnichnoye, Orlovskaya zarya, Pamyati Blynskogo, Vita, Mars, Imrus, Pamyat' Semakinu, Chistotel, Kandil' orlovskiy, Morning star. The following varieties were selected and analyzed in more detail as sources of the total amount of phenolic compounds (more than $400.0 \mathrm{mg} / 100 \mathrm{~g}$ ): 
with the Rvi6 gene -- Start, Zaryanka, Ivanovskoye, Imrus, Orlovskoye poles'ye, Zdorov'ye, Bolotovskoye, Pamyati Khitrovo, Kandil' orlovskiy; with the Rvi5 gene - Orlovsky pioneer and Chistotel; triploids Pamyat' Semakinu, Bezhin lug, Turgenevskoye, Mars, Orlovskiy partizan, Trener Petrov, Patriot, Avgusta (404,0-623,9 mg/100 g), of which the varieties Mars and Trener Petrov have the Rvi6 gene.

\section{References}

1. R. H. Liu, J. Food Sci., 78 (s1), 18-25 (2013). https://doi.org/10.1111/1750-3841.12101

2. A. Rodriguez-Mateos, D. Vauzour, C. G. Krueger, D. Shanmuganayagam, J. Reed, L. Calani, P. Mena, D. Del Rio, A. Crozier., Arch. Toxicol., 88(10), 1803-1853 (2014). http://dx.doi.org/10.1007/s00204-014-1330-7

3. Y. Aguilera, M. A. Martin-Cabrejas, E. González de Mejia, Phytochem. Rev., 15(3), 405-423 (2016). https://doi.org/10.1007/s11101-015-9443-Z

4. M. Yu. Akimov, V. N. Makarov, E. V. Zhbanova, Dostizheniya nauki i tekhniki APK, 33(2), 56-60 (2019). https://doi.org/10.24411/0235-2451-2019-10214

5. L. Panzella, M. Petriccione, P. Rega, M. Scortichini, A. Napolitano, Food Chem., 140(4), 672-679 (2013). https://doi.org/10.1016/j.foodchem.2013.02.121

6. M. Kalinowska, A. Bielawska, H. Lewandowska-Siwkiewicz, W. Priebe, W. Lewandowski, Plant Physiol. Biochem., 84, 169-188 (2014). https://doi.org/10.1016 j.plaphy.2014.09.006

7. G. P. P. Lima, F.Vianello, C. R. Corrêa, R. A. da Silva Campos, M. G. Borguini, Food Nutr. Sci., 5(11), 1065-1082 (2014). http://dx.doi.org/10.4236/fns.2014.511117

8. M. Liaudanskas, P. Viškelis, D. Kviklys, R. Raudonis, V. Janulis, Int. J. Food Prop., 18(5), 945-953 (2015). https://doi.org/10.1080/10942912.2014.911311

9. D. A. Hyson, Adv. Nutr., 2(5), 408-420 (2011). https://doi.org/10.3945/an.111.000513

10. A. Alberti, A. A. F. Zielinski, D. M. Zardo, I. M. Demiate, A. Nogueira., L. I. Mafra, Food Chem., 149, 151-158 (2014). https://doi.org/10.1016/j.foodchem.2013.10.086

11. K. Amaki, E. Saito, K. Taniguchi, K. Joshta, M. Murata, Biosci. Biotech. Bioch., 75(5), 829-832 (2011). https://doi.org/10.1271/bbb.100444

12. N. Li, J. Shi, K. Wang, Agric. Food Chem., 62(3), 574-581 (2014). https://doi.org/10.1021/jf404542d

13. L. Raudonea, R. Raudonis, M. Liaudanskas, V. Janulis, P. Viskelis, Sci. Hortic., 216, 186-192 (2017). https://doi.org/10.1016/j.scienta.2017.01.005

14. A. Francini, L. Sebastiani, Antioxidants, 2(3), 181-193 (2013). https://doi.org/10.3390/antiox2030181

15. D. Konopacka, K. Jesionkowska, D. Kruczyńska, R. Stehr, F. Schoorl, A. Buehler, S. Egger, S. Codarin, C. Hilaire, I. Höller, W. Guerra, A. Liverani, F. Donati, S. Sansavini, A. Martinelli, C. Petiot, J. Carbó, G. Echeverria, I. Iglesias, J. Bonany, Appetite, 55(3), 478-483 (2010). https://doi.org/10.1016/j.appet.2010.08.011

16. J. Bonany, C. Brugger, A. Buehler, J. Carbó, S. Codarin, F. Donati, G. Echeverria, S. Egger, W. Guerra, C. Hilaire, I. Höller, I. Iglesias, K. Jesionkowska, D. Konopacka, D. Kruczyńska, A. Martinelli, C. Petiot, S. Sansavini, R. Stehr, F. Schoorl, Food Qual. Prefer., 32(C), 317-329 (2014). https://doi.org/10.1016/j.foodqual.2013.09.010

17. E. Egorov, Zh. Shadrina, G. Kochyan, Fruit growing and viticulture of South Russia, 30(06), 182-196 (2014). http://journal.kubansad.ru/pdf/14/06/16.pdf 